\title{
Application of the Universal Soil Loss Equa- tion to Rangelands on a Per-Storm Basis
}

\author{
DOUGLAS J. TRIESTE AND GERALD F. GIFFORD
}

\begin{abstract}
The Universal Soil Loss Equation was evaluated in rangeland conditions on a per-storm basis utilizing rainfall simulator data collected on 2,805 plots representing a variety of conditions in the western United States and Australia. The popular agriculturally oriented equation explained sediment yield with a low degree of accuracy for most rangeland conditions. The equation gave its most accurate predictions on mining spoils. Optimizing the equation with suitable exponents resulted in only a slight improvement in accounting for the variability in sediment yields.
\end{abstract}

An accurate prediction of erosion in wildlands is important if a land manager or researcher hopes to assess the magnitude of the problem under specified geographic, land use, and management conditions, and as a guide in the selection of management practices for specific sites. The several erosion equations being used were developed from data collected on farmlands east of the Rocky Mountains, and little effort has been made to evaluate and adapt them to western wildlands. Thus, no erosion prediction equations have been proved "universally" applicable to wildlands, although many attempts have been made to develop erosion prediction equations for specific study areas.

One of the main objectives of this study was to apply sediment and associated plot data from various rainfall simulator studies to the parameters in the Universal Soil Loss Equation (USLE) and compare the computed results with the measured soil loss. This study pertains to sheet erosion only and all computations were done on a per-storm basis. The accuracy of the USLE is best summarized by Wischmeier (1976) as follows:

Soil losses computed by the equation must be recognized as the best available estimates rather than as absolute data. All empiricially derived prediction equations involve experimental error and potential estimation error due to the effects of unmeasured variables.

The prediction accuracy of the equation was checked against 2,300 plot-years of soil loss data from 189 field plots at widely scattered locations. The published iso-erodent map, EI distribution curves, table of soil loss ratios, and slope effect chart were used to evaluate the equation factors and predict the average annual soil loss for each of the 189 plots. The predicted loss for each plot was then

\footnotetext{
Authors are graduate assistant and associate professor, Watershed Science Unit, Range Science Department, College of Natural Resources, Utah State University, Logan 84322. Mr. Trieste is currently hydrologist with the Bureau of Land Management, Sacramento, California.

Sediment data utilized in this study were collected by several persons. Special thanks go to Dr. Will Blackburn for data from numerous plant communities in Nevada; to Dr. Gerald Williams and Dr. Frank Busby for data collected in Utah, primarily in the pinyonjuniper type; to Dr. Stan Ponce for data collected in various geologic substrata within the Price River drainage; and to Mr. Tim Burton and Mr. Mike Thompson for data collected on numerous mining sites throughout Utah.

This project was conducted in cooperation with the Utah Agricultural Experiment Station, Project 749. Journal Paper 2337, Utah Agricultural Experiment Station, Utah State University, Logan, 84322

Manuscript received October 5, 1978.
}

compared with the measured average annual soil loss for the period of research record on that plot.

The mean annual soil loss for the 189-plot sample was 11.3 tons per acre. The average prediction error was 1.4 tons, and 159 of the 189 predictions ( 84 percent) were within 2 tons of the measured losses. About 5 percent of the predictions differed from the measured losses by a little more than 4.5 tons ( 40 percent of the overall mean). Significantly, however, two-thirds of the 88 deviations that exceeded 1 ton were from comparisons with soil loss records short enough to represent less than half of a normal 20- to 22 year rainfall cycle. They were probably biased by cyclical effects as a result. When its factors are evaluated from the tables and charts, the equation predicts the average annual loss for a 22-year rainfall cycle.

Therefore, even though application of the USLE on a per-storm event may seem somewhat academic at this point, it may be justified on the basis of the following points:

1. Much of the erosion on rangelands may occur as the result of one major storm during the year. Therefore, the annual sediment yield may often approach the yield on a per-storm basis.

2. Data which are applicable to validation of the USLE are difficult to obtain. Though data discussed in this paper are on a per-storm basis, they represent a wide range of existing field conditions, they pertain only to sheet erosion, and they are associated with reasonably good soil and vegetation measures.

3 . Expected annual mean valucs of sediment yield are some function of expected annual mean values of parameters used to predict the sediment yield. However, each parameter in the USLE also has a unique distribution of values, and sediment yields at any given point in time may not be related to the values of parameters used for predicting at that point in time. This concept is important in any statistical approach to development of predictive models, and in itself warrants examination.

\section{Methods and Material}

\section{Data}

This study utilized data collected by other researchers from 2,805 simulated rainfall plots (Table 1). The data had been gathered from various rangeland in Utah, Idaho, Nevada, and Australia and represent a variety of rangeland communities, soils, slopes, rainfall intensities and geographic locations. This diversity allowed us to test the USLE under many different conditions. A Rocky Mountain infiltrometer (Dortignac 1951) was used by most of the researchers to collect their data. The Rocky Mountain infiltrometer uses a $2.5 \mathrm{ft}^{2}\left(.23 \mathrm{~m}^{2}\right)$ plot and simulates high intensity rainfall to 3.0 inches $/ \mathrm{hr}(7.5 \mathrm{~cm} / \mathrm{hr})$ or greater. The other rainfall simulators used were.

1. A modular-drip type described by Blackburn et al. (1974) which has a plot size of $9 \mathrm{ft}^{2}\left(.836 \mathrm{~m}^{2}\right)$ and can vary rainfall intensities from .2 inches $/ \mathrm{hr}$ to 3.3 inches $/ \mathrm{hr}$.

2. A modular-drip type [patterned after Meeuwig (1971) and described by Malekuti and Gifford (1978)] designed especially for use 
Table 1. List of data sources.

\begin{tabular}{lc}
\hline Date source & Number of plots \\
\hline Australia & 335 \\
Nevada & \\
$\quad$ Wet plots & 448 \\
$\quad$ Dry plots & 448 \\
Pinyon-juniper (Utah) & 1156 \\
Sagebrush (Idaho) & 279 \\
Mine sites (Utah) & 251 \\
Geologic types (Utah) & 147 \\
\hline
\end{tabular}

on steep slopes and bare soils which utilized a $4 \mathrm{ft}^{2}\left(.372 \mathrm{~m}^{2}\right)$ plot and 3 inches $/ \mathrm{hr}(7.6 \mathrm{~cm} / \mathrm{hr})$ intensities. Runoff was measured at selected time intervals during 23- to 60-minute runs. Sediment was measured by collecting the total runoff and sediment from each plot and letting the water evaporate off. The sediment remaining was then oven dried and weighed

\section{Australia Rangeland Communities}

Gifford (1978) studied infiltration and sediment production in the Northern Territory, Australia, near Alice Springs. The study was conducted under antecedent moisture conditions, with surface soils at field capacity, with surface crust scalped off under antecedent moisture conditions, and with surface crust scalped off with soil at field capacity. A Rocky Mountain infiltrometer was used to collect the data, all of which were taken on gentle slopes.

\section{Nevada Rangeland Communities}

Blackburn (1973) studied infiltration rates and sediment production in 28 plant communities and soils of five watershed areas in central and eastern Nevada. We used 15 of his plant communities for this study. Blackburn simulated rainfall from a drip type infiltrometer with application rates of $6.45 \mathrm{~cm}$ per hour and $2.54 \mathrm{~cm}$ per hour, for 30 minutes and 60 minutes, respectively. Two different soil moisture conditions were used: soil initially air dry and soil initially at field capacity.

\section{Grazing Study on Chained and Unchained Pinyon-Juniper Site in Southeastern Utah}

Busby (1977) evaluated the effect livestock grazing had on infiltration and erosion rates of unchained, debris-in-place, and windrowed pinyon-juniper sites. The study area (near Blanding, Utah) is a pinyon-juniper woodland community, with uniform, rock-free sandy-loam soils and gentle slopes. Treated areas were seeded with crested wheatgrass. A Rocky Mountain infiltrometer was used and soils were prewet to field capacity.

\section{Infiltrometer Studies on a Plowed Big Sagebrush Site}

Gifford and Busby (1974) did an intensive infiltrometer study over a 4-year period (1968-1972) on a plowed big sagebrush site near Holbrook in southern Idaho. The slopes of the area are gentle with a south aspect, and the soils are a silty loam underlain by a basaltic material. The principal plant species before treatment included big sagebrush, Sandberg bluegrass, squirreltail, Idaho fescue, brown snakeweed, small rabbitbrush, bluebunch wheatgrass, and snowleaf balsamroot. After treatment (September, 1968), principal plant species included crested wheatgrass, cheatgrass, alfalfa, intermediate wheatgrass, broom snakeweed, and small rabbitbrush. A Rocky Mountain infiltrometer was used for the study and all plots were prewet before the runs began.

\section{Infiltration Studies on Mine Spoils and Tailings}

Infiltration and sediment production data were collected by Burton (1976) and Thompson (1977) on a wide variety of mine spoils and tailings in various locations in Utah. Data were collected on both flat and steep slopes on various exposures under antecedent moisture conditions with a modular drip-type rainfall simulator. Except on a few sites, vegetation was nonexistent.

Infiltration and Erosion Studies on Pinyon-Juniper Conversion Sites in Central and Southern Utah

Research to gather information concerning infiltration rates and sediment production from converted and untreated pinyon-juniper sites in central and southern Utah was carried out by Williams et al. (1969), and Gifford et al. (1970) on 28 sites near Price, Eureka, Blanding, and Milford. All plots were prewet and a Rocky Mountain infiltrometer was used to simulate high intensity rainfall

\section{Infiltration and Erosion Studies on Different Geologic \\ Types, Price Basin}

During 1974 and 1975 a diffuse source salinity study was conducted in the Price River Basin, Utah (Ponce 1975). Data was collected from 26 different sites on 14 different geologic rock types. All infiltrometer runs were made with a Rocky Mountain infiltrometer on $10 \%$ slopes. Soils of the area are derived mainly from sedimentary rocks and glacial outwash. Principal plant communities are subalpine forest and big sagebrush with a mixture of pinyon-juniper, shadscale, and greasewood.

\section{Data Analysis}

The 2,805 plots were systematically organized so that specific questions could be answered regarding the Universal Soil Loss Equation. The questions to be answered concerned the accuracy of the equation in the following situations:

1. All 2,805 plots pooled

2. Each data source

3. Effect of different antecedent moisture conditions

4. Effect over time

5. Effect of different plant communities

6. Effect of different geologic types

7. Mine spoils

8. Effect of different rainfall application rates

9. Effect of treated versus untreated big sagebrush

10. Effect of treated versus untreated pinyon juniper

Data from the total available were, therefore, selected on the basis of relevance to these questions. The data were then further subdivided or pooled as necessary to evaluate a specific effect.

Predicted soil losses were computed by substituting the "best available numbers" into the USLE. The "best available numbers" were derived by determining a factor value as objectively as possible from instructions given in the literature for the use of the equation.

The equation was computed for each plot, and the resulting predicted sediment yield compared with the observed sediment yield for the same plot. The comparison involved two procedures:

1. Computing the ratio of predicted/observed erosion.

2. Computing the coefficient of determination $\left(R^{2}\right)$ and $F$-value for each group of data that pertained to a specific situation.

The number of ratios of predicted/observed that fit in a particular interval were tallied, and frequency diagrams were made for all plots pooled.

The correlation element ( $r$ ) between the measured sediment yield and each independent variable (i.e., the $\mathrm{R}, \mathrm{K}, \mathrm{L}, \mathrm{S}$, and $\mathrm{C}$ factors) was also computed to determine the amount each independent variable contributes to predicting sediment yield.

\section{Computation of Individual Factors \\ $R$-factor}

The rainfall erodability factor $(R)$, is the number of erosion-index units computed from the characteristics of rainfall during the period in which sediment yield is predicted. In this case,

$$
R=\frac{E \times I}{100}
$$

where:

$\mathrm{E}=$ the total kinetic energy of a storm in foot-tons per acre inch,

$I=$ the maximum 30 -min intensity of the storm.

In computing the $\mathrm{R}$-factor, two cases had to be considered depending on the data: (1) data collected with a Rocky Mountain infiltrometer in which the rainfall intensity changed throughout the run, and (2) data 
collected with a modular-drip type infiltrometer in which the rainfall intensity was held constant.

Case 1. Rainfall intensity data from the Rocky Mountain infiltrometer was collected at intervals from $0-3,3-8,8-13$, $13-18,18-23$, and $23-28$ minutes. The maximum 30-minute intensity, $I$, in this case, was taken to be the weighted average intensity of the five intervals that make up the 28 -minute period. The rainfall energy parameter, E, was figured by summing up the computed kinetic energy for each time period. This was accomplished as follows:

1. Compute kinetic energy (K.E.) for each interval from the Wischmeier and Smith (1958) regression equation

$$
Y=916+331 \log _{10} X
$$

where

$Y=$ K.E. in foot-tons per acre inch, and

$X=$ rainfall intensity in inches per hour

2. Multiply $Y$ for each interval by the rainfall amount in inches to give K.E. in foot-tons per acre.

3. Sum the K.E. from (2) to give the E-value for the simulated storm.

The above 3 -step procedure can be summarized in one equation of the form:

$$
\begin{aligned}
& E=\sum_{i=1}\left[\left(916+331 \log _{10} X_{1}\right)\left(X_{1} * T_{1}\right)\right]+ \\
& {\left[\left(916+331 \log _{10} X_{2}\right)\left(X_{2} * T_{2}\right)\right]+\ldots } \\
& \quad .+\left[\left(916+331 \log { }_{10} X_{i}\right)\left(X_{i} * T_{i}\right)\right]
\end{aligned}
$$

where:

$E=$ total kinetic energy for the simulated storm in foot-tons per acre,

$X=$ rainfall intensity in inches per hour,

$\mathrm{T}=$ time interval in which intensity was determined, and $\mathrm{n}=$ the number of intervals in which intensity was determined.

Case 2. The modular and drip type rainfall simulators operate at a constant intensity which simplifies the computation of $E$ and $I$. I is just the intensity in which the run was made and

$$
E=\left(916+331 \log _{10} X\right)(X * T)
$$

where $\mathrm{E}=$ total kinetic energy for the simulated storm in foot-tons

$\mathrm{X}=$ rainfall intensity inches per hour, and

$\mathrm{T}=$ the time interval for the complete run.

The $R$-value was adjusted to compensate for the difference between natural and simulated rainfall. This was necessary because the equation evaluated in this study is based on data from natural rainfall and the measured sediment from the infiltrometer plots is a result of action by simulated rainfall. A reliable parameter for comparing simulated rainfall to natural rainfall was provided by Meyer (1965). Since the kinetic energy of a rainstorm is proportional to rainfall erosivity, ${ }^{1}$ the ratio of the kinetic energy of a simulated rainstorm to that of a natural rainstorm would be the relative erosivity of simulated to natural rainfall: (1) drop diameter, and (2) velocity upon impact. However, drop diameter is not a concern here since it is directly proportional to the mass of a raindrop and the mass of the accumulated raindrops (rainfall amount) is the same for both simulated and natural rainfall. This leaves only the ratio of the velocities squared as a parameter for comparing simulated to natural rainfall. Mathematically, the above discussion is:

Relative erosivity $=\frac{\mathrm{M}_{s} \mathrm{~V}_{s}{ }^{2}}{\mathrm{M}_{n} \mathrm{~V}_{n}{ }^{2}}=\frac{\mathrm{K} . \mathrm{E} . \text { of simulated rainfall }}{\text { K.E. of natural rainfall }}$

where

$\mathbf{M}_{s}=$ mass of the simulated rainfall,

$\mathrm{V}_{s}=$ velocity of the simulated rainfall,

$\mathbf{M}_{n}=$ mass of the natural rainfal, and

$\mathrm{V}_{n}=$ velocity of the natural rainfall

But, $\mathbf{M}_{s}=\mathbf{M}_{n}$

1 Rainfall erosivity is a power or property of rainfall to erode a particular material (soil in this case).
Thus,

$$
\text { Relative erosivity }=\frac{\mathrm{V}_{s}{ }^{2}}{\mathrm{~V}_{n}{ }^{2}}
$$

Relative Erosivity for the Rocky Mountain Infiltrometer. A value of .43 was used as the relative erosivity ratio between the Rocky Mountain infiltrometer (Type ' $F$ ' nozzle) and natural rainfall. This can be verified by consideration of the velocities (mean drop size diameter) upon impact of natural and simulated rainfall. The mean drop diameter of a raindrop from a Type-F nozzle is approximately 3.7 $\mathrm{mm}$ and would have an impact velocity of $5.8 \mathrm{~m}$ per second with an average fall height of $2.13 \mathrm{~m}$. Natural raindrops, with a mean drop size diameter of $3.7 \mathrm{~mm}$, would have a terminal velocity (and impact velocity) of $8.8 \mathrm{~m}$ per second,

$$
\text { Relative erosivity }=\frac{\mathrm{V}_{s}{ }^{2}}{\mathrm{~V}_{n}{ }^{2}}=\frac{(5.8)^{2}}{(8.8)^{2}}=.43
$$

Relative Erosivity for Modular Infiltrometer Used in Mine Studies. The infiltrometer used by Burton (1976) and Thompson (1977) was such that the impact velocity of the simulated raindrops upon impact was $4.3 \mathrm{~m}$ per second for the $7.6 \mathrm{~cm}$ per hour intensity with which it was operated (Burton 1976). Terminal velocity for natural rainfall with an intensity of $7.6 \mathrm{~cm}$ per hour is $8.0 \mathrm{~m}$ per second. So,

$$
\text { Relative erosivity }=\frac{\mathrm{V}_{s}{ }^{2}}{\mathrm{~V}_{n}{ }^{2}}=\frac{(4.3)^{2}}{(8.8)^{2}}=0.28
$$

Relative Erosivity for Modular Infiltrometer Used in Nevada Rangeland Studies. The terminal velocity of the infiltrometer as used by Blackburn (1973) was described by Blackburn et al. (1976) to be $70 \%$ of terminal velocity when the simulated raindrops fall from a height of $2.3 \mathrm{~m}$. Thus,

$$
\text { Relative erositivity }=\frac{\mathrm{V}_{s}{ }^{2}}{\mathrm{~V}_{n}{ }^{2}}=(.70)^{2}=
$$

\section{K-factor}

The K-factor was determined directly from the soil erodibility nomograph. Most of the data used in this study included percent sand, silt, clay, and organic matter and infiltration rates, all of which are needed to solve the nomograph for $K$. The percent silt and very fine sand parameter on the nomogram was estimated by utilizing the guidelines presented by Erickson (1973). Permeability class was determined by fitting the infiltration constant to Table 2 .

Table 2. Permeability class related to infiltration constant.

\begin{tabular}{lc}
\hline \hline Permeability class & $\begin{array}{c}\text { Infiltration Constant } \\
(\mathrm{cm} / \mathrm{hr})\end{array}$ \\
\hline Very slow & $<0.15$ \\
Slow & $0.15-0.51$ \\
Moderately slow & $0.51-1.52$ \\
Moderate & $1.52-5.08$ \\
Moderately rapid & $5.08-11.29$ \\
Rapid & $>11.29$ \\
\hline
\end{tabular}

Some of the data did not include a particle size analysis. " $\mathrm{K}$ " values were then estimated from the textural class of the soil by using Erickson's guidelines (1973).

\section{LS-factor}

For the slope length, L, the length of the infiltration plot was used. $\mathrm{S}$, the slope gradient, was taken directly from the data, or in a few cases, from personal communication with the researcher who collected that data.

\section{C-factor}

The Utah Water Research Laboratory (1976) has taken " C" values for permanent pasture, rangeland, and idle land, and put them in graphical form for ease of use. All C-values were taken directly from those graphs for this study. 


\section{Improvement of Equations}

An attempt was made to improve the USLE by reducing the variability between the predicted and observed sediment yields. Each factor in the equation was optimized with an exponent by applying multiple regression techniques. In this way, all the factors could be calculated according to the literature and the equation could give better results by raising the factors to an optimum power.

The dependent variable for the equation $(Y)$, is the measured sediment yield in tons per acre for the run in which the data needed to compute the equation was obtained. The independent variables are listed in Table 3. $\log _{\mathrm{N}}(Y)=\log _{\mathrm{N}}\left(X_{1}\right)+\log _{\mathrm{N}}\left(X_{2}\right)+\log _{\mathrm{N}}\left(X_{; 3}\right)$ $+\log _{\mathrm{N}}\left(X_{4}\right)+\log _{\mathrm{N}}\left(X_{5}\right)$

Table 3. Independent variables for the USLE equation as used in the multiple regression analysis.

\begin{tabular}{|c|c|c|c|}
\hline Equation & & Number & Description \\
\hline \multirow{6}{*}{$\begin{array}{l}\text { Universal } \\
\text { Soil Loss }\end{array}$} & $\mathrm{X}_{1}$ & & Rainfall factor, " $\mathrm{R}$ ", \\
\hline & $\mathrm{X}_{2}$ & & Soil erodibility factor -- "K"' \\
\hline & $X_{: 3}^{2}$ & & $\begin{array}{l}\text { Slope length factor, "L" }= \\
(X / 72.6)^{m} \text { where } \mathrm{m}= \\
.5 \text { for } S \geq 5 \% \\
.4 \text { for } S=4 \% \\
.3 \text { for } S \leq 3 \%\end{array}$ \\
\hline & $X_{4}$ & & $\begin{array}{l}\text { Slope gradient factor, } S= \\
430 \mathrm{X}^{2}+30 \mathrm{X}+0.43\end{array}$ \\
\hline & & & 6.57415 \\
\hline & $X_{5}$ & & Cover factor, "C"' \\
\hline
\end{tabular}

where

$Y=$ measured sediment yield in tons per acre,

$X_{1}=$ rainfall factor,

$X_{2}=$ soil erodibility factor,

$X_{3}=$ slope length factor,

$X_{4}=$ slope steepness factor, and

$X_{5}=$ cover factor.

Optimizing the independent variables by multiple regression results in the following regression model:

$$
\begin{aligned}
\log _{\mathrm{N}}(\hat{Y})= & \beta_{0} \log _{\mathrm{N}}(\mathrm{c})+\beta_{1} \log _{\mathrm{N}}\left(X_{1}\right)+\beta_{2} \log _{\mathrm{N}}\left(X_{2}\right)+ \\
& \beta_{3} \log _{\mathrm{N}}\left(X_{3}\right)+\beta_{4} \log _{\mathrm{N}}\left(X_{4}\right)+\beta_{5} \log _{\mathrm{N}}\left(X_{5}\right)
\end{aligned}
$$

which is equivalent to:

$$
Y=\beta_{0} X_{1}^{\beta_{1} X_{2}}{ }^{\beta_{2} X_{3}}{ }^{\beta_{3} X_{4}}{ }^{\beta_{4}} X_{5} \beta_{5}
$$

\section{Results and Discussion}

\section{Predicted/Observed Ratios}

The USLE underestimates observed sediment yield $67.5 \%$ of the time and overestimates it $32.5 \%$ of the time (Fig. 1). The clustering in the ratio interval of $0-.25$ indicates that the largest number of predictions were approximately one-fourth of the observed value.

\section{$R^{2}$ for All Data Pooled}

The USLE explained only $10 \%$ of the total plot-to-plot variation in soil loss when all 2,805 plots were pooled. This low $R^{2}$ values does not indicate that the equation is applicable for predicting sediment yields on rangelands on a per-storm basis.

\section{Correlation Coefficients for Individual Parameters}

An analysis of the correlation coefficient $(r)$ between the observed sediment yield and the independent variables of the equation was made to determine which factors most influenced sediment yield (Table 4).
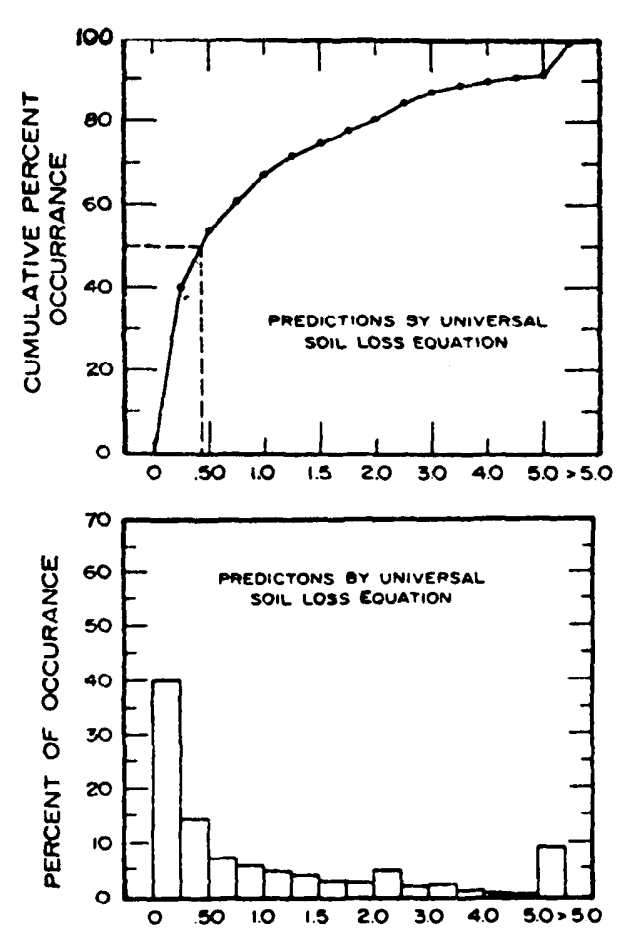

Fig. 1. Percent frequency distributions of predicted/observed ratios using data from all plots pooled.

The variable best explaining sediment yield is the slope factor (S) $\left(r^{2}=.10\right)$. The slope length factor $(\mathrm{L})$ indicated a negative relationship with soil loss, i.e., sediment yield is inversely proportional to slope length. Since only three different values of slope length were available for this study (i.e., three different infiltrometer plot lengths), it is difficult to draw any conclusions. However, the slope length factor (L) was originally derived from data collected from plots of a fixed length (72.6 feet) and then extrapolated to slopes of different lengths. Thus, under some circumstances, a negative relationship may exist between sediment yield and slope length.

Table 4. Correlation coefficients for independent variables for the Universal Soil Loss Equation using all data sources pooled $(\mathrm{N}=\mathbf{2 , 8 0 5})$.

\begin{tabular}{cc}
\hline \hline Independent variable & $r$ \\
\hline $\mathrm{R}$ & .26 \\
$\mathrm{~K}$ & .06 \\
$\mathrm{~L}$ & -.10 \\
$\mathrm{~S}$ & .32 \\
$\mathrm{C}$ & .15 \\
\hline
\end{tabular}

\section{Other Situations}

In analyzing situations 3-10 (see Data Analysis section), $R^{2}$ values were for the most part (and for all practical purposes), zero except on mining sites and a plowed big sagebrush site.

The $R^{2}$ values on individual mine sites ranged from about .70 to .99 . Representative values are shown in Figure 2 .

On a big sagebrush site (Fig. 3) prior to plowing, predictability of the equation was poor. After plowing, explained variance in sediment yields increased, but $R^{2}$ values were still not significant at the .10 level of probability. Once grazing began (trampling, compaction, etc.), very little sediment yield variance was explained.

These findings are similar to those of Gifford and Busby (1974) where it was found that easily measured soil cover characteristics do not adequately reflect the hydrologic 


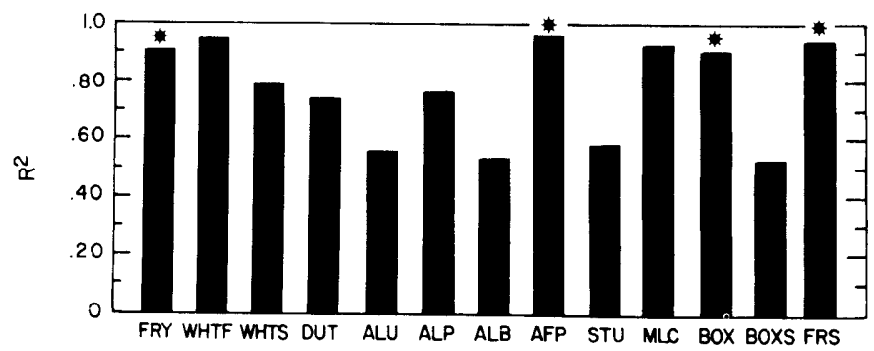

Fig. 2. R*values equal to or greater than. IO for selected mine sites sampled in 1975. indicating the amount of variance explained by the USLE. All data are from spoil deposits. $\mathrm{R}^{2}$ values significant at the .IO level of probability are marked with an asterisk.

performance of a big sagebrush site which has been grossly modified by activity such as plowing or grazing.

It is interesting to note that $R^{2}$ values obtained by Gifford and Busby (1974) using regression techniques were very close to the $R^{2}$ values obtained from the USLE evaluated in this study for the sampling periods given in Table 5 .

Table 5. Similarity in $R^{*}$ values between results from Gifford and Busby (1974) and the Universal Soil Loss Equation.

\begin{tabular}{lcc}
\hline Date & $\begin{array}{c}\text { Gifford and Busby (1974) } \\
\left(R^{2}\right)\end{array}$ & $\begin{array}{c}\text { USLE } \\
\left(R^{2}\right)\end{array}$ \\
\hline June 20,1970 & .45 & .45 \\
June 27, 1970 & .42 & .46 \\
October 3,1970 & .38 & .36 \\
July 25, 1972 & .08 & .03 \\
\hline
\end{tabular}

Modification of the USLE by Multiple Regression Techniques

Only a slight improvement in $R^{2}$ values $(0.10$ vs 0.13$)$ resulted when the factors of each equation were optimized with exponents determined by a least squares fit using multiple regression techniques to arrive at a new prediction equation for all available data. The new prediction equation was:

$$
\hat{Y}^{\prime}=.190 \mathrm{R}^{-6.5} \mathrm{~K}^{-.11 x} \mathrm{~L}^{-9.9} \mathrm{~S}^{-49} \mathrm{C}^{-.0 .5}
$$

\section{where}

$\hat{Y}$ is the new predicted sediment yield in tons/acre, and R,K,L,S,C, are the original factors as defined elsewhere.

\section{Conclusions}

As applied in this study, predictive abilities of the USLE in

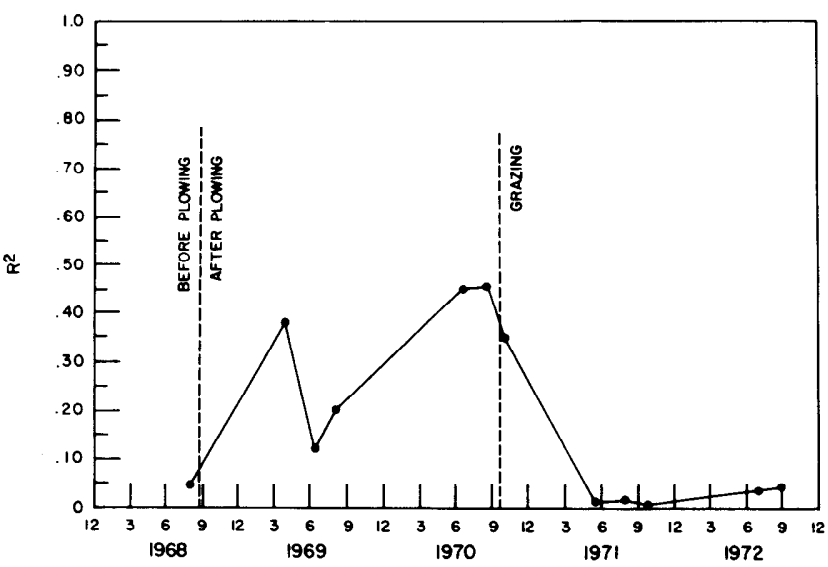

Fig. 3. $\mathrm{R}^{2}$ values for various sampling dates on a big sagebrush sampling site in Idaho indicating amount of variance explained by the USLE. No $\mathbf{R}^{2}$ values are significant at the .10 level of probability. various plant communities would seem to be, for the most part, almost random. The equation, on a per-storm basis, could not account for the variation in sediment yields as a function of soil condition, plant community, antecedent moisture conditions, or season.

Relatively good sediment predictions were made on mining spoils, indicating that perhaps the mining spoils are somewhat similar to conditions under which the equation was developed.

The factors in the USLE, as presently defined, evidently do not constitute the important parameters that explain soil loss in wildland conditions on a per storm basis, or else optimizing those factors with exponents would seemingly have accounted for the variability involved.

The designed uses of the USLE were mainly (Wischmeier 1976): (1) predicting average annual soil movement from a given slope under specified land use and management conditions, and (2) guiding the selection of conservation practices for specific sites. This study was by no means an attempt to discount use of the USLE in these areas. Though validation studies are badly necded to verify annual predictions by the USLE and modifications thereof, the equation represents a "state of the art." Where sediment yields are dominated by single storm events, application of the equation to rangeland situations may be misleading rather than useful.

\section{Literature Cited}

Blackburn, W.H. 1973. Infiltration rate and sediment production of selected plant communities and soils in five rangelands in Nevada. Agr. Exp. Sta., Univ. of Nevada, Reno. Final Rep. for BLM Contract No. 14-11-00014632. $99 \mathrm{p}$

Blackburn, W.H., R.O. Meeuwig, and C.M. Skau. 1974. A mobile infiltrometer for use on rangeland. J. Range Manage. 27:322-323.

Burton, T.A. 1976. An approach to the classification of Utah mine spoils based on surface hydrology and erosion. MS Thesis, Utah State Univ., Logan. 92 p.

Busby, F.E. 1977. Effect of livestock grazing on infiltration and erosion rates measured on grazed and ungrazed pinyon-juniper sites in southeastern Utah. PhD Diss., Utah State Univ., Logan. 130 p.

Dortignac, E.J. 1951. Design and operation of the Rocky Mountain infiltrometer. U.S. Forest Serv., Rocky Mt. Forest and Range Exp. Sta. Pap. \#5. $68 \mathrm{p}$.

Erickson, A.J. 1973. Aids for estimating soil erodability. . " $\mathrm{K}$ " value class and soil loss tolerance. U.S.D.A., Soil Conserv. Ser. 20 p.

Gifford, G.F. 1978. Infiltrometer studies in rangeland plant communities of the Northern Territory. Aust. Rangeland J. 1:142-149.

Giflord, G.F., and F.E. Busby. 1974. Intensive infiltrometer studies on a plowed big sagebrush site. J. Hydrology 21:81-90.

Gifford, G.F., G. Williams, and G.B. Coltharp. 1970. Infiltration and erosion studies on pinyon-juniper conversion sites in southern Utah. J. Range Manage. 23:402-406.

Malekuti, A., and G.F. Gifford. 1978. Natural vegetation as a source of diffuse salt within the Colorado River Basin. Water Resour. Bull. 14:195205.

Meeuwig, R.O. 1971. Infiltration and water repellency in granitic soils. U.S. Forest Serv. Res. Pap. INT-111: 20 p.

Meyer, L.D. 1965. Simulation of rainfall for soil erosion research. Trans. of the ASAE 8:63-65.

Ponce, S.L. 1975. Examination of a nonpoint source loading function for the Mancos shale wildlands of the Price River Basin, Utah. PhD Diss., Utah State Univ., Logan.

Soil Conservation Service. 1975. Procedure for computing sheet and rill erosion on project areas. U.S. Dep. Agr. Technical Release No. 51Geology. 16 p.

Thompson, K.M. 1977. Unpublished infiltrometer data.

Williams, G., G.F. Gifford, and G.B. Coltharp. 1969. Infiltrometer studies on treated vs. untreated pinyon-juniper sites in central Utah. J. Range Manage. 22:110-114.

Wischmeier, W.H. 1976. Use and misuse of the Universal Soil Loss Equation. J. Soil and Water Conserv. 31: 5-9.

$W$ ischmeier, W.H., and D.D. Smith. 1965. Predicting rainfall erosion losses from cropland east of the Rocky Mountains. Res. Serv. U.S. Dep. Agr. Agr. Handbk No. 282. 47 p. 